\title{
Intracellular immunoglobulin distribution of bone marrow plasma cells as a diagnostic aid for primary amyloidosis
}

\author{
C THielemans, W AELbReCht, D VERBEelen, G SOMERS, M DE WAELE, \\ B VAN CAMP
}

From the Department of Hematology, University Hospital of the Free University of Brussels, Laarbeeklaan 101, 1090 Brussels, Belgium

SUMMARY In order to classify the underlying disorder in four patients with biopsy-proven amyloidosis without overt monoclonal gammopathy, the cytoplasmic immunoglobulin (Ig) distribution of bone marrow plasma cells was evaluated using direct immunofluorescence microscopy. This procedure revealed the presence of a monoclonal proliferation of light chain containing plasma cells, and thus led to the diagnosis of immunoglobulin-related amyloidosis.

Amyloidosis is characterised by the deposition of typical fibrils in the extracellular space which may lead to impairment of function. These amyloid fibrils are detected by their specific staining pattern and by their optical properties as revealed by Congo red dye using polarisation microscopy. Chemical analysis of purified amyloid substance has led to the recognition of different structural proteins, which can be divided into immunoglobulin- and nonimmunoglobulin-related types. ${ }^{12}$

These studies showed that the major protein component of amyloid substance in primary amyloidosis and multiple myeloma-associated amyloidosis usually consists of a homogeneous immunoglobulin (Ig) light chain fraction, derived from the monoclonal Ig which in its turn is secreted by proliferating monoclonal plasma cells, usually situated in the bone marrow. Recently primary amyloidosis and multiple myeloma-associated amyloidosis has been termed together as "immunocyte dyscrasia-related, or immunocytic amyloidosis." 3 Although an increased number of plasma cells in the bone marrow with a monoclonal Ig in serum or urine, especially light chains, will often lead to the diagnosis of primary amyloidosis, a number of patients lack obvious signs of a monoclonal plasma cell dyscrasia. ${ }^{1}$ Cathcart et al $^{4}$ detected an $\mathrm{M}$-component in serum or urine, or both, of only seven of 14 patients with primary amyloidosis. Kyle and Bayrd ${ }^{5}$ found a serum or urine monoclonal protein in 29 of 50 patients with

Accepted for publication 15 July 1981 primary amyloidosis. Pruzanski and $\mathrm{Katz}^{6}$ detected Bence Jones proteinaemia in $56 \%$ of their patients with primary amyloidosis; Bence Jones proteinuria was present in $75 \%$ of these patients after concentrating the urine up to 3000 times.

However, massive non-selective proteinuria can mask their detection, ${ }^{4}$ Since bone marrow plasma cells are the major source of serum Ig, alterations in serum concentrations reflect the intracellular Ig distribution of plasma cells. ${ }^{7-9}$

Study of Ig distribution by immunofluorescence microscopy was of major diagnostic significance in the four patients with biopsy-proven amyloidosis, whose data are presented.

\section{Patients and methods}

\section{PATIENTS}

The major findings in our four patients with primary amyloidosis are summarised in Table 1. The diagnosis of amyloidosis was based on the histological examination of a biopsy specimen of the diseased tissue and on the demonstration of the characteristic emerald-green birefringence with polarisation microscopy. Osteolytic lesions were excluded by a radiological survey of the skeleton. Microscopical examination of bone marrow smears, obtained from the sternum or the iliac crest, or both, revealed a normal number of plasma cells with moderate polymorphism. The protein profile of the serum was examined by cellulose acetate electrophoresis and densitometric scanning. All patients 
Table 1 Basic data of four patients with immunoglobulin-related amyloidosis

\begin{tabular}{|c|c|c|c|c|c|c|c|c|}
\hline \multirow[t]{2}{*}{ Patient } & \multirow[t]{2}{*}{$\begin{array}{l}\text { Age } \\
(y r)\end{array}$} & \multirow[t]{2}{*}{ Sex } & \multirow[t]{2}{*}{ Symptoms } & \multirow[t]{2}{*}{$\begin{array}{l}\text { Positive } \\
\text { tissue biopsy }\end{array}$} & \multirow[t]{2}{*}{$\begin{array}{l}\text { Bone marrow } \\
\text { plasma cells }\end{array}$} & \multicolumn{3}{|c|}{$\begin{array}{l}\text { Serum Ig concentrations* } \\
(m g / d l)\end{array}$} \\
\hline & & & & & & $\operatorname{Ig} A$ & $I g M$ & $I g G$ \\
\hline 1 & 66 & $\mathbf{F}$ & $\begin{array}{l}\text { Weight loss } \\
\text { Median nerve entrapment } \\
\text { Sclerodemia-like skin infiltration } \\
\text { Polyarthropathy (glenohumeral- } \\
\text { articulation) } \\
\text { Macroglossia-deglutition disturbance }\end{array}$ & Tongue & $8 \%$ & 72 & 66 & 740 \\
\hline 2 & 52 & $\mathbf{M}$ & $\begin{array}{l}\text { Weight loss } \\
\text { Anorexia } \\
\text { Hepatomegaly }\end{array}$ & $\begin{array}{l}\text { Kidney } \\
\text { Liver }\end{array}$ & $6 \%$ & 220 & 44 & 670 \\
\hline 3 & 53 & $\mathbf{M}$ & $\begin{array}{l}\text { Weight loss } \\
\text { Anorexia } \\
\text { Orthostatic hypotension } \\
\text { Right heart failure } \\
\text { Gastrointestinal motility disturbances } \\
\text { Sensory deficits in lower limbs }\end{array}$ & Kidney & $3 \%$ & 55 & 50 & 425 \\
\hline 4 & 57 & $\mathbf{M}$ & $\begin{array}{l}\text { Nephrotic syndrome } \\
\text { Anasarca } \\
\text { Sexual impotence } \\
\text { Hepatomegaly }\end{array}$ & Liver & $4 \%$ & 88 & 110 & 300 \\
\hline
\end{tabular}

*Normal range: $\mathrm{IgG}=800-1500 \mathrm{mg} / \mathrm{dl}$.

IgA $=150-300 \mathrm{mg} / \mathrm{dl}$.

IgM $=800-1500 \mathrm{mg} / \mathrm{dl}$.

showed a hypogammaglobulinaemia, which was further analysed by radial immunodiffusion for the quantification of $\operatorname{IgG}, \operatorname{IgA}$ and IgM. ${ }^{12}$

To investigate a possible underlying monoclonal plasma cell proliferation, the serum, urine and a bone marrow cell suspension were further processed using specific antibody test systems.

AGAR- AND IMMUNOELECTROPHORESIS OF SERUM AND URINE

Serum and a freshly collected morning specimen of urine was examined by agarelectrophoresis as described by Wieme, ${ }^{13}$ and by immunoelectrophoresis according to Radl.14

A portion of urine samples was concentrated fiftyfold on Minicon B15 (Amicon Co, Lexington, Mass, USA) and investigated as such, using rabbit antisera, which were specific for the immunoglobulin heavy chain class and light chain type determinants.

CYTOPLASMIC IG DISTRIBUTION OF BONE

MARROW PLASMA CELLS

Approximately one millilitre of bone marrow was aspirated in $0.5 \mathrm{ml}$ of $5 \%$ EDTA in phosphatebuffered saline (PBS) from the iliac crest or from the sternum. Five hundred cells were counted after staining the smears with May-Grünwald-Giemsa. Bone marrow suspensions were obtained according to the technique of Hijmans et al. ${ }^{15}$

Briefly, $25 \mu \mathrm{l}$ of a washed cell suspension of $1.5 \times 10^{6}$ mononuclear cells $/ \mathrm{ml}$ is sedimented in a cytocentrifuge. The use of this instrument ensures the presence of large numbers of washed cells on a small area of a microscope slide. The same cell suspension is used for as many preparations as possible. With this method, mutually comparable slides from one cell suspension are obtained. The reliability of the method and reproducibility of figures have been amply documented. ${ }^{7-11}$

The slides were fixed, washed, and incubated with specific fluorochrome-conjugated antisera for $30 \mathrm{~min}$ at room temperature. Detailed specifications have been published.16 After the final washing, the slides were mounted in buffered glycerol, covered with a glass slide and sealed. All preparations were viewed with a Leitz Dialux fluorescence microscope. Examination of comparable cytocentrifuge slides of one suspension gives information on the distribution pattern of Ig-containing cells.

Using an FITC-conjugated antihuman immunoglobulin (anti-HuIg) (IgG + IgA + IgM) reagent, calculation of the relative and absolute number of cytoplasmic-Ig-positive plasma cells was made. The number of cytoplasmic positive cells is counted in respect to the cytoplasmic-Ig-negative mononuclear cells. At least 500 fluorescent cells were assessed.

\section{Results}

In the Figure the agarelectrophoretic patterns of the serum and of the fiftyfold concentrated urine samples of the four patients are shown. Only case 1 demonstrated an M-component in the serum as well as in the urine. Case 4 and in a minor degree case 3 had a non-selective proteinuria. Using specific antisera directed against the hidden deter- 


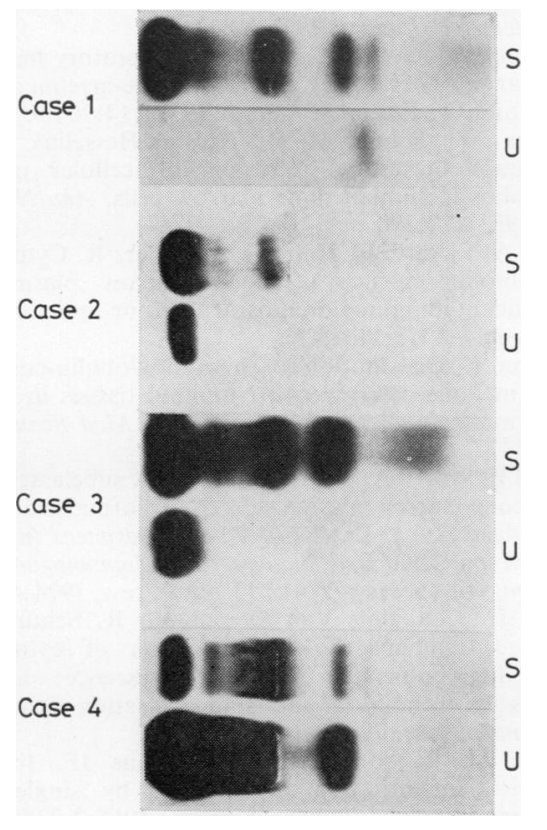

Agarelectrophoretic patterns of serum $(S)$ and concentrated urine $(U)$ of four patients.

minant of light chain type kappa $(\kappa)$ or lambda $(\lambda)$, immunoelectrophoretical analysis indicated the presence of monoclonal free light chain of $\kappa$ type in case 1 . In two other patients only a trace amount of $\kappa$ (case 2 ) or $\lambda$ (case 3 ) light chains was detected. The tests of the urine sample of case 4, studied at different concentrations, were not conclusive for the presence of a monoclonal Ig fraction.

Table 2 summarises our findings regarding the class and light chain distribution of bone marrow plasma cells. The class profile was normal, but the $\kappa: \lambda$ ratio was clearly deviated towards one type. Furthermore there was an excess of light chainsecreting plasma cells when compared to the sum of the heavy chain class-containing cells. It was obvious that in all patients a monoclonal plasma cell proliferation existed, secreting only one light chain type. In three of our patients a bone marrow aspirate from the iliac crest as well as from the sternum was taken. An identical distribution pattern of plasma cells was found, indicating the diffuse nature of the plasma cell proliferation in the marrow.

\section{Discussion}

The pathogenetic role of monoclonal $\mathrm{Ig}$ in the development of amyloid deposits in primary amyloidosis has now been well recognised. This knowledge is derived from biochemical and amino acid sequence analyses, which show the relation of the amyloid fibril composition to Bence Jones proteins ${ }^{2}$ and is in accordance with the presence of monoclonal Ig or light chains in the serum or urine, or both, of many of the patients affected with primary amyloidosis. ${ }^{4-6} 17$

From our study and others ${ }^{4}$ it follows that the M-component can be very minimal, and sometimes undetectable. In addition, the concentration of urine samples with massive proteinuria and the presence of free light chains of both types, can mask minute amounts of monoclonal free light chains. ${ }^{4}$ From a diagnostic point of view, electrophoresis techniques will not always be helpful in delineating the underlying plasma cell dyscrasia in primary amyloidosis.

Although a slight increase in the number of plasma cells $^{4} \mathbf{6}$ and especially an increase in their "reactive" morphology, is known to exist in primary amyloidosis, such findings have no discriminant value in the absence of an M-component, since this picture can also be seen in many chronic disorders. The intracellular Ig distribution of bone marrow plasma cells is more valuable as it reflects very closely the serum Ig pattern.?

Studies of this kind using immunofluorescence microscopy in multiple myeloma, benign monoclonal gammopathy, and Waldenström's macroglobulinaemia, have clearly shown the presence of

Table 2 Cytoplasmic immunoglobulin distribution (\%) in bone marrow plasma cells

\begin{tabular}{|c|c|c|c|c|c|c|c|}
\hline Case No & $I g^{*}$ & $I g G \dagger$ & $\operatorname{Ig} A \dagger$ & $I g M \dagger$ & $I g D \dagger$ & $\kappa: \lambda$ & Heavy:light $\ddagger$ \\
\hline $\begin{array}{l}1 \\
2 \\
3 \\
4\end{array}$ & $\begin{array}{l}10 \\
5 \\
3 \\
6 \cdot 4\end{array}$ & $\begin{array}{l}75 \\
39 \cdot 5 \\
51 \\
71 \cdot 9\end{array}$ & $\begin{array}{l}20 \\
54 \\
36 \\
17 \cdot 1\end{array}$ & $\begin{array}{c}5 \\
5 \\
13 \\
10.9\end{array}$ & $\begin{array}{l}0 \\
1 \cdot 5 \\
0 \\
0\end{array}$ & $\begin{array}{c}130 \\
7 \\
0.3 \\
4.9\end{array}$ & $\begin{array}{l}0.10 \\
0.35 \\
0.70 \\
0.57\end{array}$ \\
\hline $\begin{array}{l}\text { Controls } \\
\text { Mean } \\
\text { SEM }\end{array}$ & $\begin{array}{l}\text { 20) } \\
3 \cdot 5 \\
0.5\end{array}$ & $\begin{array}{l}54 \\
3 \cdot 1\end{array}$ & $\begin{array}{r}37 \cdot 6 \\
3 \cdot 3\end{array}$ & $\begin{array}{l}7 \cdot 4 \\
1 \cdot 1\end{array}$ & $\begin{array}{l}\text { nd } \\
\text { nd }\end{array}$ & $\begin{array}{l}1 \cdot 3 \\
0 \cdot 2\end{array}$ & $\begin{array}{l}1 \cdot 1 \\
0 \cdot 2\end{array}$ \\
\hline
\end{tabular}

* Percent of bone marrow plasma cells containing cytoplasmic Ig.

tThe distribution of cells bearing heavy chain classes expressed as a percentage of all cells positively with an anti-Ig-FITC. $\ddagger$ The ratio of cells positive for heavy chains :cells positive for light chains.

nd $=$ not done. 
monoclonal plasma cell proliferation in the bone marrow. ${ }^{9}$

In this respect, our finding of a monoclonal light chain-secreting plasma cell proliferation in all four patients with primary amyloidosis, thereby extending the observations of Hogewind et al, ${ }^{18}$ adds support to the association of an underlying plasma cell dyscrasia with this disease. In addition, the diffuse spread of the light chain-secreting plasma cell clone throughout the bone marrow is comparable to the one found in multiple myeloma or benign monoclonal gammopathy. The presence of a residual population of polyclonal plasma cells indicates the low proliferating activity of the light chain-secreting clone, which is also seen in benign monoclonal gammopathy. ${ }^{9}$

However, a discrepancy exists between the extremely low serum or urine concentrations, or both, of the monoclonal proteins and the monoclonal plasma cell proliferation. One explanation may be that the monoclonal light chains secreted by the bone marrow plasma cells, are precipitated as amyloid or picked up by phagocytic cells-for example, macrophages, endothelial cells, where they are modified by proteolysis to form amyloid fibrils. Another mechanism, perhaps less convincing, but analogous to the rapid clearance of the coagulation factor $\mathrm{X}$ from the circulation, ${ }^{19}$ may be the direct binding of amyloidogenic light chains to amyloid fibrils exposed to the bloodstream.

We are indebted to Professor W Hijmans for helpful criticism, to $\mathrm{L}$ Broodtaerts for excellent technical assistance and to $\mathrm{S}$ Goossens for help in preparing the manuscript.

\section{References}

${ }^{1}$ Glenner GG, Terry WD, Isersky C. Amyloidosis: its nature and pathogenesis. Semin Hematol 1973;10:65-86.

${ }^{2}$ Terry WD, Page DL, Kimura S, Isobe T, Osserman EF, Glenner GG. Structural identity of Bence Jones and amyloid fibril proteins in a patient with plasma cell dyscrasia and amyloidosis. J Clin Invest 1973;52:1276-81.

${ }^{3}$ Glenner GG. Amyloid deposits and amyloidosis: the $\beta$-fibrilloses. $N$ Engl J Med 1980;302:1283-92, 1333-43.

${ }^{4}$ Cathcart ES, Ritchie RF, Cohen AS, Brandt K. Immunoglobulins and amyloidosis: an immunologic study of sixty-two patients with biopsy-proved disease. Am J Med 1972;52:93-101.
${ }^{5}$ Kyle RA, Bayrd ED. Amyloidosis: review of 236 cases. Medicine (Baltimore) 1975;54:271-99.

${ }^{6}$ Pruzanski W, Katz A. Clinical and laboratory findings in primary generalized and multiple-myeloma-related amyloidosis. Can Med Assoc J 1976;114:906-9.

${ }^{7}$ Hijmans W, Schuit HRE, Hulsing-Hesselink E. An immunofluorescence study on intracellular immunoglobulins in human bone marrow cells. Ann NY Acad Sci 1971;177:290.

${ }^{8}$ Morell A, Skvaril F, Hijmans W, Scherz R. Cytoplasmic immunofluorescence of bone marrow plasma cells producing immunoglobulins of the four IgG subclasses. J Immunol 1975;115:579.

${ }^{9}$ Turesson I. Distribution of immunoglobulin-containing cells in bone marrow and lymphoid tissues in patients with monoclonal gammopathy. Acta Med Scand 1978; 203:247.

10 Skvaril F, Morell A. Distribution of IgA subclasses in sera and bone marrow plasma cells of 21 normal individuals. In: Mestecky J, Lawton AR, eds. Advances in experimental medicine and biology. The immunoglobulin $A$ system, vol 45. New York: Plenum Press, 1974:433-5.

${ }^{11}$ Vossen JM, Langlois Van Den Bergh R, Schuit HRE, Radl J, Hijmans W. The detection of cytoplasmic immunoglobulins by immunofluorescence: improvements in techniques and standardisation procedures. J Immunol Methods 1976;13:71-82.

${ }^{12}$ Mancini G, Carbonara AO, Heremans JF. Immunochemical quantitation of antigens by single radial immunodiffusion. Immunochemistry 1965;2:235.

${ }^{13}$ Wieme RJ. Agar gel electrophoresis. Amsterdam: Elsevier, 1965.

${ }^{14}$ Radl J. Light chain typing of immunoglobulins in small samples of biological material. Immunology 1970;19:137.

${ }^{15}$ Hijmans W, Schuit HRE, Klein F. An immunofluorescence procedure for the detection of intracellular immunoglobulins. Clin Exp Immunol 1969;4:457.

${ }^{16}$ Van Camp B, Reynaert Ph, Broodtaerts L. Studies on the origin of the precursor cells in multiple myeloma, Waldenström's macroglobulinaemia and benign monoclonal gammopathy. 1 Cytoplasmic isotype and idiotype distribution in peripheral blood and bone marrow. Clin Exp Immunol $1981 ; 44: 82-9$.

${ }^{17}$ Isobe T, Osserman EF. Patterns of amyloidosis and their association with plasma cells dyscrasia, monoclonal immunoglobulins and Bence Jones proteins. $N$ Engl $J$ Med 1974;290:473-7.

${ }^{18}$ Hogewind BL, Schipperheyn JJ, Van Furth R. Amyloidose en paraproteinemie. Ned Tijdschr Geneeskd 1975;119: 1799-1806.

${ }^{19}$ Furie B, Voo L, McAdam KP, Furie BC. Mechanism of factor $\mathrm{X}$ deficiency in systemic amyloidosis. $N$ Engl J Med 1981;304:827-30.

Requests for reprints to: Dr Chris Thielemans, Department of Hematology, AZ-VUB, Laarbeeklaan 101, 1090 Brussels, Belgium. 